\title{
Urethritis in women attending an STD clinic
}

\author{
JOHAN E WALLIN, ${ }^{*}+$ SUMNER E THOMPSON, ${ }^{*} \neq$ AKBAR ZAIDI, * AND \\ KWEI-HAY WONG $\S$ \\ From the *Venereal Disease Control Division (Bureau of State Services) and the $\S$ Venereal Disease \\ Research Branch (Bureau of Laboratories), Center for Disease Control; and the Departments of \\ \$Medicine and †Dermatology, Emory University School of Medicine, Atlanta, Georgia, USA
}

SUMMARY Of an unselected group of 159 women attending a sexually transmitted disease (STD) clinic $20 \%$ (32) had symptoms of urethritis. A positive correlation existed between the finding of more than 10 polymorphonuclear leucocytes (PMNL) per high-power field in the Gram.stained urethral smear and the presence of Neisseria gonorrhoeae, Chlamydia trachomatis, and Trichomonas vaginalis. Conversely, these organisms were rarely isolated if no PMNL were present. Fewer cultures gave positive results for these organisms if micturition had occurred les $\$$ than four hours before examination. $C$ trachomatis was recovered from the urethra or endocervix $\vec{x}_{7}$ in $29 / 150(19 \cdot 3 \%)$ and from the urethra alone in six women. In contrast, $N$ gonorrhoeae was never recovered from the urethra in the absence of endocervical infection. Of the 159 women $10 \%$ had bacteriuria due to non-sexually transmissible agents; $50 \%$ had asymptomatic bacteriuria. All, however, had other urethral pathogens isolated as well. Thus, sexually transmitted disease agents: are highly prevalent in women attending an STD clinic who have signs and symptoms of urethritis As in non-gonococcal urethritis in men, $C$ trachomatis may be an important cause of urethritis ing women.

\section{Introduction}

The diagnosis of urethritis in men is relatively simple since it is established by using two objective criteria: the presence of urethral discharge and the finding of polymorphonuclear leucocytes (PMNL) in the urethral smear. ${ }^{1}$ Thus, it is possible to speak of symptomatic urethritis in men-a common condition in sexually transmitted disease (STD) clinics-in which there is no dysuria, urgency, or frequency, yet the objective criteria of discharge only after urethral stripping and of PMNL in the exudate are still met.

On the other hand, it is difficult to establish this diagnosis with certainty in women because frequency and dysuria are common complaints and cystitis and bacteriuria are frequent diagnoses. ${ }^{2}$ No objective criteria have been established to help distinguish urethritis from infections occurring elsewhere in the female urinary tract.

The aims of this study were to define the occurrence of sexually transmissible agents in the urethras of an unselected population of women attending an STD clinic and to correlate these with the number of

Address for reprints: Dr S E Thompson, Technical Information Services, Center for Disease Control, Atlanta, Georgia 30333, USA

Accepted for publication 6 July 1980
PMNL in the urethral smear-that is, to determine iæू these agents were colonisers or were causing am inflammatory process.

\section{Patients and methods}

STUDY POPULATION

All women over 18 years of age attending a suburban STD clinic in Atlanta, Georgia, USA, for the first. time between November 1977 and April 1978 were potential candidates for the study. Those who had taken antibiotics during the two weeks before their first visit or who were pregnant or did not agree to $\frac{}{8}$ participate were excluded. Women were purposelyב. given no specific instructions about voiding before ज examination; thus none was excluded because she had micturated just before examination.

One physician (JW) obtained informed written $\omega$ consent and then interviewed and examined all the women.

CLINICAL PROCEDURES

A speculum pelvic examination was performed and material obtained for smears and cultures from three sites: the urethra (calcium alginate swab); the cervical canal, after cleansing externally with sterile saline@ 
(cotton swab); and the posterior vaginal pool (cotton swab). Gram-stained urethral smears were scanned under low power to locate the area of greatest leucocyte density where the average number of PMNL in five high-power fields $(\times 970)$ was calculated. The smears were then examined for Gram-negative intracellular diplococci.

\section{CULTURE}

Specimens were cultured for Neisseria gonorrhoeae, Chlamydia trachomatis, Mycoplasma hominis, Ureaplasma urealyticum, Gardnerella (Corynebacterium) vaginalis, Trichomonas vaginalis, and Candida species. The posterior forniceal specimens were cultured for only the last three agents, since they are more commonly found in this location than in either the urethra or endocervix. The order in which urethral and endocervical specimens were collected was randomly changed every second week to avoid selection bias for any particular organism.

Patients were instructed how to clean the periurethral area and to catch a midstream urine sample in a sterile container. Clean-voided urine was cultured quantitatively to identify the pathogens commonly associated with non-sexually transmitted urinary tract infections, the Enterobacteriaceae and aerobic cocci.

\section{MICROBIOLOGY}

Urethral specimens

Swabs for the isolation of $C$ trachomatis were placed in a buffered sucrose phosphate transport medium, immediately snap-frozen in an acetone-dry ice slush, and stored at $-70^{\circ} \mathrm{C}$ until thawed for culture in the IUDR-treated McCoy cell system. ${ }^{3}$ Another swab was rinsed thoroughly in $0.6 \mathrm{~m}$ ' of trypticase soy broth; one drop $(0 \cdot 1 \mathrm{ml})$ was examined immediately for trichomonads and others were plated on to peptone-starch-dextrose agar, " "V" agar $^{5}$ for the isolation of $G$ vaginalis, Saboraud's chloramphenicol agar for the isolation of yeasts, and Thayer-Martin medium for the isolation of $N$ gonorrhoeae. The remainder was placed into two tubes of Diamond's medium $^{6}$ for the isolation of $T$ vaginalis. The plates for isolation of $N$ gonorrhoeae and $G$ vaginalis were placed into a candle-extinction jar and incubated at $35^{\circ} \mathrm{C}$ before transport to the laboratory. The last urethral swab was placed into mycoplasma transport medium $^{7}$ and handled exactly like the specimens for chlamydia until thawed for culture of $U$ urealyticum and $M$ hominis.

\section{Endocervical specimens}

The procedure outlined for urethral swabs was followed, except that an individual cotton swab was used for each culture.
Posterior forniceal specimens

Cotton swabs were cultured for $G$ vaginalis, $T$ vaginalis, and yeasts in most patients.

\section{Urine specimens}

A calibrated loop was used to plate clean-voided urine on to eosin-methylene blue agar and 5\% sheep blood agar for the quantitative estimation of organisms.

Smears and wet mounts were examined at the clinic; none of the laboratory personnel knew the clinical diagnosis.

\section{STATISTICAL ANALYSIS}

We used multivariate regression analysis to test for the statistical significance of the association between the type of microbial flora isolated from the urethra, endocervix, or vaginal pool and the presence or absence of urethral inflammation (presence of PMNL). We also used $\chi^{2}$ analysis with Yates's correction to analyse the contingency tables and calculated predictive values. The predictive value of a positive test result-a measure of the probability that a positive test result correctly indicates infectionwas calculated according to the following formula:

$$
\frac{\text { (Prevalence of disease) } \times(\text { Sensitivity of test })}{\text { (Prevalence) (Sensitivity) }+(1-\text { Prevalence) (1-Specificity) }} \times 100
$$

The higher the positive predictive value, the more frequently a positive test result correlates with the disease state.

\section{Results}

One hundred and fifty-nine women ranging in age from 18 to 40 years (mean $23 \pm 6 \cdot 3$ ) were studied; 87 were white and 72 black. Since there were no statistically significant differences between white and black women for the variables considered, data were not subdivided by race.

We chose the breakpoints of more than four hours after micturition and more or less than 10 PMNL/hpf in the urethral smear by using discriminant analysis. This procedure let us select values that best identified patient groups-the numbers of PMNL and the presence or absence of pathogens in the urethra identified by culture.

The major reasons for attending the clinic were venereal infections in sexual partners $(49 \%)$ and symptoms of genital infection (45\%). The presenting symptoms of all 159 women are summarised in table I. Overall, $45.5 \%$ of women had no PMNL in their urethral smear, 39\% had 1-10 PMNL, and 15.5\% more than $10 \mathrm{PMNL} / \mathrm{hpf}$. 
TABLE I Presenting symptoms in 159 unselected women attending an STD clinic

\begin{tabular}{llr}
\hline Symptom & No of patients & $\%$ \\
\hline Vaginal discharge & 79 & $50 \cdot 0$ \\
Dysuria without frequency & 16 & $10 \cdot 1$ \\
Frequency without dysuria & 25 & $15 \cdot 7$ \\
Both dysuria and frequency & 15 & $9 \cdot 4$ \\
Vulval or vaginal pruritus & 53 & $33 \cdot 3$ \\
Lower abdominal pain & 12 & $7 \cdot 5$ \\
Genital ulcer & 3 & $1 \cdot 9$ \\
Other & 28 & $17 \cdot 6$ \\
No problem & 43 & $27 \cdot 0$ \\
\hline
\end{tabular}

*Most patients had more than one presenting symptom

\section{CULTURE}

The micro-organisms isolated, with particular reference to those from the urethra, are given in table II. No significant differences were found in the

TABLE II Micro-organisms isolated from the endocervix and urethra of women attending an STD clinic

\begin{tabular}{|c|c|c|c|}
\hline Organism isolated & $\begin{array}{l}\text { No } \\
\text { examined }\end{array}$ & $\begin{array}{l}\% \\
\text { Infected } \\
\text { at any } \\
\text { site }\end{array}$ & $\begin{array}{l}\% \\
\text { Infected at } \\
\text { urethra } \\
\text { only }\end{array}$ \\
\hline $\begin{array}{l}\text { Neisseria gonorrhoeae } \\
\text { Chlamydia trachomatis } \\
\text { Gardnerella vaginalis } \\
\text { Ureaplasma urealyticum } \\
\text { Mycoplasma hominis } \\
\text { Trichomonas vaginalis } \\
\text { Candida species }\end{array}$ & $\begin{array}{l}159 \\
150 \\
119 \\
119 \\
119 \\
158 \\
159\end{array}$ & $\begin{array}{l}20 \cdot 7 \\
19 \cdot 3 \\
26 \cdot 9 \\
65 \cdot 5 \\
47 \cdot 9 \\
39 \cdot 6 \\
17 \cdot 6\end{array}$ & $\begin{array}{l}0 \\
20 \cdot 7 \\
34 \cdot 4 \\
35 \cdot 9 \\
24 \cdot 6 \\
7 \cdot 8 \\
3 \cdot 6\end{array}$ \\
\hline
\end{tabular}

*Percentage of those patients infected at any site

isolation rates of pathogens from the urethra of patients either with or without the symptoms of urethral inflammation, dysuria and frequency. Nor was there a significant correlation between symptoms and the number of PMNL found on urethral smear. However, there was a significant association between the presence of more than $10 \mathrm{PMNL} / \mathrm{hpf}$ and the isolation of $N$ gonorrhoeae, $C$ trachomatis, and $T$ vaginalis (table III). C trachomatis and the gonococcus were rarely isolated if there were no signs of urethral inflammation. The number of PMNL had no correlation with the isolation of any other microorganisms.

In all patients fewer cultures gave positive results if micturition occurred less than four hours before examination (table IV), but this finding was TABLE IV Comparison of urethral isolation rates with hours elapsed since last micturition

\begin{tabular}{lll}
\hline & \multicolumn{2}{c}{$\%$ Isolations from urethra } \\
\cline { 2 - 3 } Urethral isolate & 0.4 hours $(n=137)$ & $>4$ hours $(n=22)$ \\
\hline Neisseria gonorrhoea & $10 \cdot 2$ & $27 \cdot 3$ \\
Chlamydia trachomatis & $10 \cdot 6$ & $33 \cdot 3^{*}$ \\
Gardnerella vaginalis & $18 \cdot 8$ & $55 \cdot 5$ \\
Ureaplasma urealyticum & $52 \cdot 0$ & $55 \cdot 5$ \\
Mycoplasma hominis & $33 \cdot 0$ & $66 \cdot 6$ \\
Trichomonas vaginalis & $13 \cdot 2$ & $22 \cdot 8$ \\
Candida species & $17 \cdot 5$ & $18 \cdot 2$ \\
\hline
\end{tabular}

*Statistically significant difference $\left(\chi_{1}^{2}=7 \cdot 7, P=0 \cdot 02\right)$

statistically significant only for $C$ trachomatis. In addition, numbers of PMNL in the urethral smear were significantly greater when the time-lapse between micturition and examination was more than four hours (table V).

TABLE V Relationship between the number of leucocytes in urethral smears and the hours elapsed since last micturition

\begin{tabular}{|c|c|c|c|c|c|}
\hline \multirow{3}{*}{$\begin{array}{l}\text { No of hours } \\
\text { since last } \\
\text { micturition }\end{array}$} & \multicolumn{5}{|c|}{$P M N L$ in the urethral smear/hpf } \\
\hline & \multicolumn{2}{|l|}{$0-10$} & \multicolumn{3}{|l|}{$>10$} \\
\hline & $\begin{array}{l}\text { No of } \\
\text { patients }\end{array}$ & $\%$ & $\begin{array}{l}\text { No of } \\
\text { patients }\end{array}$ & $\%$ & Total \\
\hline $\begin{array}{l}0-4 \\
>4 \\
\text { Total }\end{array}$ & $\begin{array}{r}90 \\
7 \\
97\end{array}$ & $\begin{array}{r}92 \cdot 8 \\
7 \cdot 2 \\
100 \cdot 0\end{array}$ & $\begin{array}{l}47 \\
15 \\
62\end{array}$ & $\begin{array}{r}75 \cdot 8 \\
24 \cdot 2 \\
100 \cdot 0\end{array}$ & $\begin{array}{r}137 \\
22 \\
159\end{array}$ \\
\hline
\end{tabular}

$\chi_{1}^{2}=9 \cdot 2, p=0 \cdot 01$

TABLE III Correlation of urethral pathogens with urethral leucocyte counts

\begin{tabular}{|c|c|c|c|c|c|c|c|c|}
\hline \multirow[b]{2}{*}{ Urethral isolate } & \multicolumn{6}{|c|}{ Urethral leucocyte count/hpf } & \multicolumn{2}{|c|}{ Statistical values } \\
\hline & $\begin{array}{l}\frac{0}{\text { No of }} \\
\text { specimens }\end{array}$ & $\%$ Positive & $\begin{array}{l}\frac{1-10}{\text { No of }} \\
\text { specimens }\end{array}$ & $\%$ Positive & $\begin{array}{l}\frac{>10}{\text { No of }} \\
\text { specimens }\end{array}$ & $\%$ Positive & $\chi^{2 *}$ & $\mathbf{P}$ \\
\hline $\begin{array}{l}\text { Neisseria gonorrhoeae } \\
\text { Chlamydia trachomatis } \\
\text { Gardnerella vaginalis } \\
\text { Ureaplasma urealyticum } \\
\text { Mycoplasma hominis } \\
\text { Trichomonas vaginalis } \\
\text { Candida species } \\
\text { No pathogen isolated }\end{array}$ & $\begin{array}{l}71 \\
71 \\
55 \\
55 \\
55 \\
70 \\
71 \\
55\end{array}$ & $\begin{array}{r}0 \cdot 0 \\
5 \cdot 6 \\
25 \cdot 5 \\
40 \cdot 0 \\
29 \cdot 1 \\
21 \cdot 4 \\
16 \cdot 9 \\
21 \cdot 8\end{array}$ & $\begin{array}{l}26 \\
22 \\
20 \\
20 \\
20 \\
26 \\
25 \\
20\end{array}$ & $\begin{array}{r}11 \cdot 5 \\
4 \cdot 6 \\
10 \cdot 0 \\
50 \cdot 0 \\
30 \cdot 0 \\
34 \cdot 6 \\
16 \cdot 0 \\
25 \cdot 0\end{array}$ & $\begin{array}{l}62 \\
57 \\
44 \\
44 \\
44 \\
62 \\
62 \\
44\end{array}$ & $\begin{array}{r}27 \cdot 4 \\
26 \cdot 3 \\
11 \cdot 4 \\
40 \cdot 9 \\
43 \cdot 2 \\
43 \cdot 5 \\
8 \cdot 1 \\
9 \cdot 1\end{array}$ & $\begin{array}{l}22 \cdot 66 \\
13 \cdot 43 \\
4 \cdot 31 \\
0 \cdot 64 \\
2 \cdot 36 \\
7 \cdot 44 \\
2 \cdot 43 \\
3 \cdot 62\end{array}$ & $\begin{array}{l}<0 \cdot 001 \\
<0 \cdot 01 \\
\text { NS } \\
\text { NS } \\
\text { NS } \\
<0 \cdot 05 \\
\text { NS } \\
\text { NS }\end{array}$ \\
\hline
\end{tabular}

${ }^{*} \chi^{2}$ value with $2 \mathrm{df}$ comparing $0,1-10$, and $>10 \mathrm{PMNL} / \mathrm{hpf}$ with positive culture results 
If the urethral PMNL count alone was used to discriminate between those with gonorrhoea (urethral or cervical or both), the positive predictive value of more than $10 \mathrm{PMNL} / \mathrm{hpf}$ in the urethral smear for the presence of gonorrhoea was only $49.6 \%$ and for identifying chlamydial and trichomonal infections $49.0 \%$ and $45.4 \%$ respectively. The positive predictive value depends heavily on the prevalence of the infections in the population tested. Our results should not be extrapolated to other population groups with radically different prevalences of infection.

The wet-mount examination of urethral material for the identification of $C$ albicans gave a positive result in only one patient out of 21 with positive urethral culture results. $T$ vaginalis was identified in the urethral wet mount in $67 \%$ of those with a positive culture result.

Ten per cent $(15 / 149)$ of the women had $\geqslant 10^{5}$ bacterial colony-forming units $/ \mathrm{mm}^{3}$ isolated from clean-voided urine specimens. The organisms isolated were Escherichia coli (8); Klebsiella pneumoniae (2); Enterobacter aerogenes (1); Proteus mirabilis (1); and group B streptococci (3). All these women also had one or more other urethral pathogens isolated at the same time. Of these 15 women with bacteriuria, eight were asymptomatic but six had more than 10 urethral PMNL/hpf. Of the seven with symptoms, five had more than 10 PMNL/hpf.

\section{Discussion}

Urethral symptoms are common in women attending our clinic, and urethritis-here defined as an inflammatory response within the urethra-is a distinct entity. Although there was poor correlation between the degree of inflammation found in urethral smears and symptoms, a potential or real pathogen could be isolated from most women with urethral leucocytosis. This is not surprising, since in men it is clear that urethral symptoms do not necessarily correlate with the degree of inflammation that is present. Men with significant urethral leucocytosis may be asymptomatic, and conversely symptoms can exist when there is no evidence of inflammation.

Oriel et $a l^{8}$ empirically chose 10 or more $\mathrm{PMNL} / \mathrm{hpf}$ in a urethral smear or urine specimen as diagnostic of urethritis in men. Swartz et al ${ }^{1}$ refined that number in men to four or more PMNL/hpf in a urethral smear and $\geqslant 5 / \mathrm{hpf}$ in a urine specimen. It seems a logical step to attempt to apply this finding to women; indeed there appear to be close parallels. We found only one published report on the numbers of PMNL in urethral smears of women with urethritis; ${ }^{9} 10 \mathrm{PMNL} / \mathrm{hpf}$ was chosen as the cut-off point, but no rationale was given for this decision. In this study we selected this figure on the basis of a statistical analysis of our population. Ten $\mathrm{PMNL} / \mathrm{hpf}$ is the value which best divides women with urethral pathogens from those without. Women with classical non-sexually transmitted bacteriuria rarely had urethral leucocytosis. However, the finding of significant urethral leucocytosis is not an absolute indicator of urethral infection. About 3\% of women with gonococci and $6 \%$ with $C$ trachomatis isolated from their urethras had PMNL counts of less than $10 / \mathrm{hpf}$.

Relying on symptoms alone, we underestimated the number of women with urethral colonisation. We were able to culture potential pathogens from the urethras of $80 \%$ and to demonstrate evidence of inflammation in an additional $8 \%$ of women who had no urinary tract symptoms. We recovered $C$ trachomatis from the urethra alone in $21 \%(6 / 29)$ of those with chlamydial infection. Conversely, the gonococcus was not recovered solely from the urethra in any case, a finding which has been observed in other studies. ${ }^{1011}$ The organism most frequently isolated was $U$ urealyticum. The pathogenic status of this organism remains to be defined, but some evidence exists that it is sometimes a cause of urethritis in men. ${ }^{12} 13$

We examined the washout effect of urine on the numbers of PMNL and organisms in urethral specimens. There was a significantly lower number of $\mathrm{PMNL} / \mathrm{hpf}$ in the smears of those women who had urinated less than four hours before examination. There was also a tendency towards lower isolation rates for all organisms, although this was significant only for $G$ vaginalis.

The possibility that some of these organisms were vaginal contaminants introduced into the urethra on the swabs cannot be excluded. Although the finding of more than $10 \mathrm{PMNL} / \mathrm{hpf}$ on the urethral smear is a helpful indicator of genital infection, it does not distinguish between aetiological agents. However, a negative result on Gram stain for the gonococcus and on a wet mount for $T$ vaginalis should markedly increase the suspicion of a chlamydial infection. The presence of more than $10 \mathrm{PMNL} / \mathrm{hpf}$ in a smear together with a history of a sexual partner with urethritis should further increase the likelihood of isolating either $N$ gonorrhoeae or $C$ trachomatis from the urogenital tract (table VI).

Finally, $10 \%$ of our study population had organisms often associated with bladder or upper urinary tract infections. We did not attempt to confirm this diagnosis by repeated cultures, nor did we examine the role of these organisms in causing acute urethritis. However, the finding of bacteriuria in $10 \%$ of this unselected population raises the 
question of whether screening for common urinary tract pathogens should not be a routine investigation in an STD clinic.

TABLE VI Correlation of urethral leucocytosis and contact history with isolation of gonococci or chlamydia or both

\begin{tabular}{|c|c|c|c|c|c|}
\hline \multirow{3}{*}{$\begin{array}{l}\text { Isolation } N \\
\text { gonorrhoeae } \\
\text { or chlamydia } \\
\text { or both }\end{array}$} & \multicolumn{5}{|c|}{ No of urethral PMNL/hpf } \\
\hline & \multicolumn{2}{|c|}{$\begin{array}{l}>10: \text { partner with } \\
\text { urethritis }\end{array}$} & \multicolumn{3}{|c|}{$\begin{array}{l}\text { S10: partner without } \\
\text { urethritis }\end{array}$} \\
\hline & No & $\%$ & No & $\%$ & Total \\
\hline $\begin{array}{l}\text { Positive } \\
\text { Negative } \\
\text { Total }\end{array}$ & $\begin{array}{l}41 \\
42 \\
83\end{array}$ & $\begin{array}{r}49 \cdot 4 \\
50 \cdot 6 \\
100 \cdot 0\end{array}$ & $\begin{array}{l}10 \\
66 \\
76\end{array}$ & $\begin{array}{r}13 \cdot 2 \\
86 \cdot 8 \\
100 \cdot 0\end{array}$ & $\begin{array}{r}51 \\
108 \\
159\end{array}$ \\
\hline
\end{tabular}

$\chi_{1}^{2}=23 \cdot 9, \mathrm{P}<0 \cdot 001$

The authors sincerely thank Gil Reising, Jan Bullard, Carolyn Ramsey, and James Thomas for their technical excellence in providing microbial isolations for this study. We would also like to thank the staff of the DeKalb County Venereal Disease Clinic, where this work was performed.

\section{References}

1. Swartz SL, Kraus SJ, Herrmann KL, et al. Diagnosis and etiology of non-gonococcal urethritis. $J$ Infect Dis 1978; 138: 445-54.

2. Dans PE, Klaus B. Dysuria in women. Johns Hopkins Journal 1976; 138: 13-18.

3. Wentworth BB, Alexander R. Isolation of Chlamydia trachomatis by use of 5-iodo-2-deoxyuridine-treated cells. Appl Microbiol 1974; 27:912-6.

4. Dunkelberg WE, McVeigh I. Growth requirements of $\mathbb{D}$ Haemophilus vaginalis. Antonie van Leeuwenhoek 1969;35: 129-45.

5. Greenwood JR, Pickett MJ, Martin WJ, Mack EG. Haemophilus vaginalis (Corynebacterium vaginale): method for isolation and rapid biochemical identification. Health $L a b$. Sci 1977; 14: 102-6.

6. Diamond LS. The establishment of various trichomonads of animal and man in axenic cultures. $J$ Parasitol 1957; 43:488-98.

7. Velleca WM, Bird BR, Forrester FT. Laboratory Diagnosis of $\stackrel{0}{=}$ Mycoplasma Infections. Atlanta, Georgia, USA: US Depart- or ment of Health, Education and Welfare, Public Health $V$ Service, Center for Disease Control, 1975.

8. Oriel J, Reeve $P$, Wright $J$, et al. Chlamydial infection of the $\mathrm{G}$ male urethra. Br J Vener Dis 1976; 52:46-51.

9. Earle J. Significance of leucocytes in smears taken from the음 female urinary meatus. $B r J$ Vener Dis 1977;53:56-7.

10. Lucas JB, Price EV, Thayer JD, et al. Diagnosis and treatment of gonorrhea in the female. N Engl J Med 1967;276:1454-9.

11. Schmale JD, Martin JE jun, Domescik G. Observation on the $\mathbb{D}$ culture diagnosis of gonorrhea in women. JAMA 1969;210: 312-4.

12. Csonka GW. Non-gonococcal urethritis. Br $J$ Vener Diš 1965;41:1-8.

13. Bowie WR. Etiology and treatment of nongonococcal $\vec{C}$ urethritis. Sex Transm Dis 1978;5:27-33. 